Volume 2 Nomor 1, Mei 2021: h. 66 - 77

P-ISSN: 2722-4465, E-ISSN: 2746-8151

Lisensi Creative Commons Atribusi-NonCommercial 4.0 Internasional

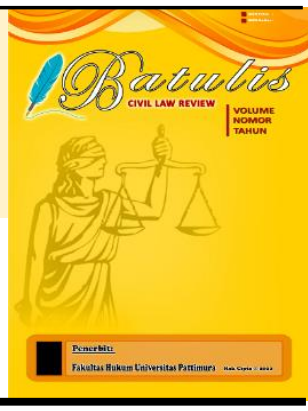

\title{
Perlindungan Hukum Bagi Perusahaan Debitur Pailit dalam Menghadapi Pandemi Covid 19
}

\author{
Ronald Saija ${ }^{1}$, Kadek Agus Sudiarawan ${ }^{2}$ \\ 1, Fakultas Hukum Universitas Pattimura, Ambon, Indonesia. \\ 2, Fakultas Hukum Universitas Udayana, Denpasar, Indonesia \\ E-mail: ronaldreagensaija@gmail.com
}

\begin{tabular}{l}
\multicolumn{1}{c}{ Dikirim: 14/04/2021 } \\
\hline Info Artikel \\
\hline Keywords: \\
Bankruptcy; Debitor; Covid \\
19. \\
\hline Kata Kunci: \\
Pailit; Debitur; Covid 19.
\end{tabular}

Dipublikasi: 31/05/2021 \begin{abstract}
The emergence of the Covid-19 pandemic on global economic development has an impact not only on the world economy and investment, but also correlates with aspects of legal development, especially business economy law. One of the areas of business economy law that has also undergone changes in an effort to accommodate the development of modern business transaction practices is bankruptcy law. The purpose of this research is to examine the preventive efforts made by Debtors at Bankrupt Companies to reduce bankruptcy caused by Covid-19 and solutions to protect debtors in companies experiencing bankruptcy. The research method used is juridical normative, primary and secondary legal materials with a statutory approach and a conceptual approach. The results showed that the regulations regarding bankruptcy law in various countries, including Indonesia, tended to change. For example in Europe, in the last few decades European countries have argued that the existing insolvency legal framework has not been able to provide a better economic legal scheme compared to liquidation schemes, so that changes in the substance of bankruptcy have occurred in almost all aspects of the country including the Union. Europe, the American continent, the Asian continent, the African continent, and the Australian continent.
\end{abstract}

Abstrak
Munculnya pandemi Covid-19 pada perkembangan
perekonomian secara global membawa pengaruh tidak hanya
terhadap dunia ekonomi dan investasi, namun juga berkorelasi
terhadap aspek perkembangan hukum terutama hukum
ekonomi bisnis. Salah satu bidang hukum ekonomi bisnis yang
turut mengalami perubahan sebagai upaya untuk
mengakomodir perkembangan praktek transaksi bisnis modern
adalah hukum kepailitan. Tujuan dari penelitian ini yaitu
mengkaji upaya preventif yang dilakukan oleh Debitur pada
Perusahaan Pailit untuk meredam kepailitan yang disebabkan
Covid 19 dan solusi untuk melindungi pihak debitur dalam
perusahaan yang mengalami pailit. Metode penelitian yang
digunakan yaitu yuridis normatif, bahan hukum primer dan
sekunder dengan pendekatan undang-undang dan pendekatan
konseptual. Hasil penelitian menunjukan bahwa pengaturan


DOI:

10.47268/ballrev.v2i1.474 mengenai hukum kepailitan di berbagai negara termasuk Indonesia cenderung mengalami perubahan. Sebagai contoh di Eropa, beberapa dekade terakhir negara-negara Eropa berpendapat bahwa kerangka hukum kepailitan (insolvensi) yang ada belum mampu memberikan skema hukum ekonomi yang lebih baik jika dibandingkan dengan skema likuidasi, sehingga perubahan substansi kepailitan yang terjadi di hampir semua aspek negara termasuk Uni Eropa, benua Amerika, benua Asia, benua Afrika, dan benua Australia.

\section{Pendahuluan}

Perkembangan perekonomian secara global membawa pengaruh tidak hanya terhadap dunia ekonomi dan investasi, namun juga berkorelasi terhadap perkembangan hukum terutama hukum ekonomi. Salah satu bidang hukum ekonomi yang turut mengalami perubahan sebagai upaya untuk mengakomodir perkembangan praktek transaksi bisnis modern adalah hukum kepailitan. Pengaturan mengenai hukum kepailitan di berbagai negara termasuk Indonesia cenderung mengalami perubahan. Sebagai contoh di Eropa, beberapa dekade terakhir negara-negara Eropa berpendapat bahwa kerangka hukum insolvensi yang ada belum mampu memberikan skema ekonomi yang lebih baik dibandingkan skema likuidasi sehingga perubahan substansi kepailitan terjadi di hampir semua negara uni eropa (Wessels, 2017).

Secara substansi dan struktur walaupun kebijakan terkait kepailitan di masing-masing negara uni eropa menunjukkan beberapa perbedaan namun sebagian besar kebijakan ini memiliki titik berat pada prosedur penyelamatan perusahaan ("corporate rescue procedure"), sebagai alternatif dari prosedur likuidasi. Prosedur dalam kepailitan yang dipakai oleh sebagian besar negara-negara uni eropa ini mengacu pada Chapter 11 of the United States Bankruptcy Code.

Indonesia dalam menjawab tantangan perekonomian dunia juga melakukan langkah perbaikan terkait dengan hukum kepailitan. Perbaikan peraturan perundangundangan terkait kepailitan diawali tahun 1998 dengan lahirnya Peraturan Pemerintah Pengganti Undang-undang Nomor 1 Tahun 1998 tentang Perubahan atas Undang-Undang Kepailitan. Peraturan ini lahir pada saat Indonesia dilanda krisis moneter pada tahun 1998 yang mengakibatkan sejumlah perusahaan nasional maupun multinasional di Indonesia mengalami pailit. Kemudian pada tahun 2004 sebagai penyempurnaan dari substansi pengaturan kepailitan sebelumnya serta untuk menjawab kebutuhan dan perkembangan hukum masyarakat, ditetapkanlah Undang-Undang Nomor 37 Tahun 2004 tentang Kepailitan dan Penundaan Kewajiban Pembayaran Utang (selanjutnya disebut UUKPKPU). Undang-undang ini dalam penjelasan umumnya disebutkan memiliki cakupan yang lebih luas baik dari segi norma, ruang lingkup materi, maupun proses penyelesaian utangpiutang. Cakupan yang lebih luas tersebut diperlukan, karena adanya perkembangan dan kebutuhan hukum dalam masyarakat sedangkan ketentuan yang selama ini berlaku belum memadai sebagai sarana hukum untuk menyelesaikan masalah utang-piutang secara adil, cepat, terbuka, dan efektif.

Bentuk sengketa kepailitan dimasukkan dalam kategori permohonan. Kendatipun sengketa kepailitan berbentuk permohonan, namun undang-undang sendiri menetapkan bahwa terhadapnya pengadilan memberikan keadilannya dalam bentuk suatu putusan. Putusan kepailitan adalah bersifat serta merta dan konstitutif, yakni meniadakan keadaan 
dan menciptakan keadaan hukum baru, dalam putusan hakim dalam kepailitan terdapat tiga hal yaitu: 1) pernyataan bahwa si debitor pailit; 2) pengangkatan seorang hakim pengawas yang ditunjuk dari hakim pengadilan; dan 3) penetapan kurator (Saija, 2018a: 12-13).

Penyelesaian sengketa kepailitan menjadi bagian penting yang mendukung kemudahan berusaha di Indonesia. Hal ini menjadi acuan investor untuk memastikan apakah utang dapat dibayarkan, sekaligus juga memastikan apakah perusahaan yang memiliki kesulitan keuangan mempunyai mekanisme untuk direstruktur utangnya. Selain itu penyelesaian sengketa kepailitan dapat menggambarkan apakah mekanisme penyelesaian likuidasi dapat diselesaikan secara transparan dengan hasil yang terbaik.

Penataan Regulasi harus dilakukan melalui evaluasi atas berbagai peraturan agar sejalan dengan jiwa Pancasila, amanat konstitusi dan kepentingan nasional. Dengan dilakukannya penilaian terhadap peraturan perundang-undangan tidak hanya akan memperbaiki materi hukum yang ada (existing), namun juga memperbaiki sistem hukum yang mencakup materi hukum; kelembagaan dan penegakan hukum; pelayanan hukum; serta kesadaran hukum masyarakat, dengan berbagai upaya yang dilakukan Bangsa Indonesia dalam menangani segala regulasi Kepailitan pada saat ini telah memberikan berbagai perspektif menarik di kemudian hari.

Penanganan kasus kepailitan dewasa ini, kasus kepailitan yang berakhir pada sikap saling lapor dan saling gugat antara debitor, kreditor dan kurator. Hal-hal semacam ini akan menjadi penyebab blundernya proses penegakan hukum di Indonesia. Sehingga satu masalah belum selesai sudah ditumpangi oleh masalah yang lain. Bahkan tidak jarang persoalan-persoalan hukum yang dibawa ke pengadilan melahirkan putusanputusan yang tidak sinkron satu sama lain. Hal ini dapat terjadi karena diantara aparat penegak hukum tidak ada kesamaan sudut pandang dalam mendudukkan suatu permasalahan. Sehingga tidak salah opini yang berkembang di masyarakat bahwa lembagalembaga penegakan hukum dimanfaatkan oleh orang-orang yang ingin memperkeruh tujuan dari penegakan hukum yang semakin jauh dari asas keadilan dan kepastian hukum (Saija, 2021: 8).

Setelah adanya persoalan munculnya pandemi Corona Virus Deseased bulan Desember 2019 (selanjutnya disebut covid 19) yang berawalan di Wuhan - Republik Rakyat Tiongkok (RRT). Segala penyusunan regulasi dalam sengketa kepailitan menjadi berat untuk dilakukan, mengingat dalam jangka waktu yang relatif singkat penademi Covid 19 telah meluluhlantakan regulasi dunia dalam berbagai bidang kehidupan bisnis termasuk kepailitan perusahaan.

Pailit pada dasarnya merupaka suatu hal, dimana keadaan debitur (pihak yang berhutang) yang mempunyai dua atau lebih kreditur dan tidak membayar sedikitnya satu utang yang telah jatuh waktu dan dapat ditagih. Berhenti membayar bukan berarti sama Sekali tidak membayar, tetapi dikarenakan suatu hal pembayaran akan hutang tersebut tidak berjalanasebagaimana mestinya, jadi apabila debitur mengajukan permohonan pailit, maka debitur tersebut tidak dapat membayar hutang-hutangnya atau tidak mempunyai pemasukkan lagi bagi perusahaannya untuk membayar hutang (Saija, 2018: 115).

Berdasarkan persoalan diatas, maka dapat memberikan beberapa isu menarik dalam mengkaji persoalan evaluasi kepailitan yang sedang terjadi dalam dunia bisnis yakni: pertama, bagaimana upaya preventif yang dilakukan oleh Debitur pada Perusahaan Pailit untuk meredam kepailitan yang disebabkan Covid 19 dalam perspektif?, dan kedua, 
bagaimana solusi untuk melindungi pihak debitur dalam perusahaan yang mengalami pailit. Bberbagai analisis dan evaluasi hukum merupakan upaya untuk melakukan penilaian terhadap hukum, dalam hal ini peraturan perundang-undangan sebagai hukum positif, yang dikaitkan dengan struktur hukum dan budaya hokum, dalam kelompok kerja ini, analisis dan evaluasi hukum dilakukan terhadap setiap peraturan perundang-undangan yang telah diinventarisasi dengan menggunakan instrumen penilaian yang dikembangkan oleh Badan Pembinaan Hukum Nasional, yakni 5 Dimensi. Instrumen penilaian 5 Dimensi ini meliputi: Pertama, Penilaian kesesuaian antara jenis, hierarki, dan materi muatan; Kedua, Penilaian Kejelasan Rumusan; Ketiga, Penilaian kesesuaian norma; Keempat, Penilaian potensi disharmoni pengaturan; Kelima, Penilaian efektivitas implementasi peraturan. Penilaian dilakukan secara komprehensif baik dari tataran normatif maupun praksis. Hasil analisis dan evaluasi ini dapat menjadi masukan perbaikan yang objektif terhadap peraturan perundang-undangan yang ada dan dengan demikian diharapkan dapat menjadi bahan pembangunan hukum di Indonesia.

\section{Hasil dan Pembahasan}

\subsection{Preventif Perusahaan Pailit dalam Pandemi Covid 19}

Selama hampir 100 (seratus) tahun keberadaan Faillisementverordening kemudian dilakukan perubahan pada tahun 1998 seiring dengan krisis keuangan di Indonesia, dimana Pemerintah menerbitkan Peraturan Pemerintah Pengganti Undang-Undang Nomor 1 Tahun 1998 tentang Perubahan atas Undang-Undang Kepailitan, yang ditetapkan menjadi undangundang dengan Undang-Undang Republik Indonesia Nomor 4 Tahun 1998 tentang Perubahan Atas Undang-Undang Tentang Kepailitan Menjadi Undang-Undang. Ketentuan UU Kepailitan dan PKPU yang diterapkan di Indonesia selama hampir 14 (empat belas) tahun keberlakukannya, mengalami beberapa permasalahan terkait dengan ketentuan norma yang ada dalamnya yang dianggap rentan dengan penyalahgunaan yang dapat merugikan pihak debitor dan kreditor sehubungan dengan penyelesaian kepailitan, sehingga kepailitan menjadi momok dalam penyelesaian bisnis dikarenakan sangat mudahnya mekanisme penjatuhan pailit hanya berdasarkan bukti sederhana dengan mekanisme yang tidak relevan dengan prinsip hukum kebebasan hakim pada umumnya untuk menilai perkara, akibatnya banyak perusahaan yang sehat dapat menjadi pailit dan justru merugikan-kreditor pada umunnya dan debitor yang melaksanakan perusahaannya yang memiliki solvabilitas yang baik justru dirugikan akibat sistem kepailitan dalam UUKPKPU yang masih terdapat kelemahan pada sistem hukum dan kelembagaan pelaksana kepailitan.

Penyelesaian utang dengan lembaga kepailitan berakibat harta benda debitor dalam keadaan disita oleh pengadilan dan selanjutnya menjadi kewenangan kurator untuk mengurus harta kekayaan tersebut hingga proses kepailitan berakhir, termasuk pemberesan terhadap utang-utangnya. Oleh karena itu, dalam prakteknya seringkali kepailitan dipersepsikan bukan sebagai jalan keluar namun lebih sering mengandung konotasinegatif. Hal ini kemudian berimbas menurunkan kepercayaan publik terhadap kemampuan seorang direksi atau komisaris perusahaan untuk mengelola suatu perusahaan, sehingga dalam undang-undang yang mengatur mengenai perseroan terbatas menjadi syarat bagi direksi dan dewan komisaris (Lihat Pasal 93 dan Pasal 110 UU PT).

Seiring dengan perkembangan masyarakat terhadap penyelesaian kepailitan, Bank Dunia menetapkan resolving insolvency sebagai salah satu indikator kemudahan dalam 
berusaha (ease of doing business) yang menyoroti beberapa diantaranya terkait dengan costs dan recovery assets yang relatif rendah.

Ada beberapa upaya preventif yang harus diperhatikan oleh undang-undang kepailitan suatu negara agar undang-undang tersebut dapat memenuhi beberapa kebutuhan dunia usaha, baik nasional maupun internasional.Demikian pula seharusnya dengan undang-undang kepailitan yang berlaku di Indonesia dalam menghadapi pandemi Covid 19, yaiu:

1) Pembatasan investasi dan bisnis

Dalam Undang-undang kepailitan seyogjanya memuat ketentuan-ketentuan yang dapat diterima secara global (globally accepted principles).ketentuan-ketentuan tersebut harus sejalan dengan hukum kepailitan dari Negara-negara para pemodal (investor) dan kreditor asing yang diinginkan oleh pemerintah dan dunia usaha Indonesia untuk menanamkan modalnya dan memberikan kredit bagi kepentingan dunia usaha Indonesia. Oleh karena itu, undang-undang kepailitan Indonesia bukan saja harus sejalan dengan falsafah Pancasila, tetapi hendaknya juga memuat globally accepted principles dari suatu undang-undang kepailitan modern saat ini.

2) Memberi manfaat dan perlindungan yang seimbang bagi kreditor dan debitor Undang-undang kepailitan diadakan untuk memberikan manfaat dan perlindungan kepada para kreditor apabila debitor tidak membayar utangutangnya. Dengan undang-undang kepailitan, diharapkan para kreditor dapat memperoleh akses terhadap harta kekayaan dari debitor yang dinyatakan pailit karena tidak mampu lagi membayar utang-utangnya. Namun demikian, manfaat dan perlindungan yang diberikan oleh undang-undang kepailitan bagi kepentingan kreditor dan para stakeholder kreditor tidak boleh sampai merugikan kepentingan debitor dan para stakeholder debitor yang bersangkutan.

3) Putusan pernyataan pailit tidak dapat dijatuhkan terhadap debitor yang masih solven

Undang-undang kepailitan seyogjanya memuat syarat bukan hanya debitor tidak membayar utang kepada salah satu kreditornya, tetapi juga tidak membayar sebagian besar atau lebih dari 50\% utangnya. Apabila debitor tidak membayar hanya kepada satu kreditornya yang tidak menguasai sebagian besar utang debitor sedangkan kepada para kreditor yang lain masih tetap melaksanakan kewajibannya dengan baik, maka kejadian itu bukan kasus yang harus diperiksa oleh pengadilan niaga, tetapi kasus pengadilan perdata biasa.

4) Keadaan diam (stand still atau stay).

Undang-undang kepailitan seyogianya menentukan putusan pengadilan atas permohonan pernyataan pailit yang diajukan oleh seorang kreditor harus berdasarkan persetujuan para kreditor lain melalui lembaga rapat para kreditor (creditor meeting). Dipihak lain sekalipun permohonan pernyataan pailit dapat diajukan oleh debitor sendiri, namun putusan pernyataan pailit itu seyogianya tidak dapat dimbil oleh pengadilan tanpa disetujui oleh semua atau mayoritas kreditor.

5) Persetujuan putusan pailit harus disetujui oleh para kreditor mayoritas Undang-undang kepailitan seharusnya menganut ketentuan mengenai berlakunya keadaan diam (stand still atau stay) yang berlaku secara otomatis (berlaku demi hukum). Dengan kata lain, memberlakukan automatic stand still atau automatic stay, sejak permohonan pernyataan pailit didaftarkan dipengadilan. Hal 
ini demi melindungi para kreditor dari upaya debitor untuk menyembunyikan atau mengalihkan sebagian atau seluruh harta kekayaan debitor kepada pihak lain yang dapat merugikan kreditor.

6) Mengakui hak separatis kreditor pemegang hak jaminan

Lembaga hak jaminan harus dihormati oleh undang-undang kepailitan.Di dalam ilmu hukum perdata, seorang pemegang hak jaminan (hak agunan) mempunyai hak yang disebut hak separatis.Hak separatis adalah hak yang diberikan oleh hukum kepada kreditor pemegang hak jaminan bahwa barang jaminan (agunan) yang dibebani dengan hak jaminan tidak termasuk harta pailit.

7) Proses putusan pernyataan pailit tidak berkepanjangan

Undang-undang kepailitan harus menjamin proses kepailitan berjalan tidak berlarut-larut. Dalam undang-undang kepailitan harus ditentukan batas waktu bagi pengadilan untuk telah memriksa dan memutuskan permohonan pernyataan pailit. Batas waktu itu tidak boleh terlalu lama tetapi juga tidak boleh terlalu pendek karena hanya akan mengakibatkan dihasilkannya putusan pengadilan yang mutunya mengecewakan.

8) Proses putusan pernyataan pailit terbuka untuk umum

Proses kepailitan harus dapat diketahui oleh masyarakat luas karena putusan pailit terhadap seorang debitor berdampak luas dan menyangkut kepentingan banyak pihak.

9) Pengurus perseroan debitor yang mengakibatkan perseroan pailit harus bertanggung jawab pribadi

Undang-undang kepailitan seharusnya dimuat asas bahwa pengurus yang karena kelalaiannya atau karena ketidakmampuannya telah menyebabkan perseroan dalam keadaan yang sulit, harus bertanggung jawab secara pribadi.

10) Perbuatan-perbuatan yang merugikan harta pailit adalah tindak pidana.

Suatu undang-undang kepailitan sebaiknya sekaligus memuat juga ketentuanketentuan sanksi pidana terhadap debitor yang telah berada dalam keadaan keuangan yang insolven atau menuju kearah keadaan keuangan yang melakukan perbuatan-perbuatan yang merugikan kreditor tertentu atau kreditor pada umumnya.Selain itu harus memuat pula ketentuan-ketentuan sanksi pidana terhadap kreditor tertentu yang bersekongkol atau berkonspirasi dengan debitor insolven untuk menguntungkan kreditor tertentu tetapi merugikan para kreditor lainnya.

\subsection{Solusi Perlindungan Debitur Pailit dalam Pandemi Covid 19}

\subsubsection{Pemberlakuan Force Majeure}

Perikatan adalah suatu hubungan hukum yang bersifat harta kekayaan antara dua orang atau lebih, atas dasar mana pihak yang satu berhak (kreditur) dan pihak lain berkewajiban (debitur) atas sesuatu prestasi. Pada perikatan, jika debitur tidak memenuhi kewajibannya secara sukarela dengan itikad yang baik dan sebagaimana mestinya maka kreditur dapat meminta bantuan hukum agar ada tekanan kepada debitur supaya ia memenuhi kewajibannya.

Menentukan suatu hubungan hukum itu merupakan perikatan, pada mulanya para sarjana menggunakan ukuran dapat "dinilai dengan uang". Suatu hubungan dianggap dapat dinilai dengan uang jika kerugian yang diderita seseorang dapat dinilai dengan uang. Objek perikatan dapat berupa memberikan sesuatu, berbuat, dan tidak berbuat sesuatu. Pada perikatan yang berupa memberikan sesuatu prestasinya melalui penyerahan suatu 
barang misalnya penjual berkewajiban menyerahkan barangnya atau orang yang menyewakan berkewajiban memberikan kenikmatan atas barang yang disewakan. Berbuat sesuatu adalah setiap prestasi untuk melakukan sesuatu.

Perjanjian pinjam meminjam antara kreditur dan debitur sesuai dengan pasal 1320 KUH Perdata maupun Pasal 1338 ayat (1) KUH Perdata. Adanya kesepakatan para pihak dalam suatu proses perjanian pinjam meminjam merupakan salah satu unsur yang mengikat kedua belah pihak, hal yang sama juga merupakan suatu keabsahan sebagai undang-undang diantara para pihak.

Proses perjanjian pinjam meminjam antara debitur dan kreditur dapat diberlakukan force majeure dalam situasi pandemi Covid 19. Situasi pandemi Covid 19 merupakan salah satu bencana non alam yang ditetapkan oleh Pemerintahan Republik Indonesia, yang dimaksud dengan Force majeure adaah suatu keadaan yang tidak dapat diketahui sebelumnya, yang menyebabkan kesukaran dalam pelaksanaan perjanjian, yang menybabkan terhalangnya pemenuhan perikatan (Prawirohamidjojo \& Pohan, 1984: 52).

Dari pengertian tersebut nampak bahwa tidak terlaksananya apa yang dijanjikan itu disebabkan oleh hal-hal yang sama sekali tidak dapat diduga dan dimana ia tidak dapat berbuat apa-apa terhadap keadaan atau peristiwa yang timbul diluar dugaan tadi. Dengan perkataan lain, tidak terlaksananya perjanjian atau kelambatan dalam pelaksanaannya itu bukanlah disebabkan karena kelalaiannya. Keadaan itu haruslah diluar kekuasaan debitur dan memaksa, juga keadaan yang timbul itu harus berupa suatu keadaan yang tidak dapat diketahui pada waktu perjanjian dibuat.

Force majeure diatur pada pasal 1244 KUHPerdata yang menyebutkan bahwa : jika ada alasan untuk itu, debitur harus dihukum mengganti biaya, rugi, dan bunga apabila ia tak dapat membuktikan, bahwa hal tidak atau tidak pada waktu yang tepat dilaksanakannya perikatan itu, disebabkan karena suatu hal tak terduga, pun tak dapat dipertanggungjawabkan padanya, kesemuanya itu pun jika itikad buruk tidaklah ada pada pihaknya.

Keadaan yang menimbulkan force majeure harus terjadi setelah dibuatnya persetujuan. Karena jika pelaksanaan prestasinya sudah tidak mungkin sejak dibuatnya persetujuan, maka persetujuan tersebut batal demi hukum. Hal-hal tentang force majeure terdapat didalam ketentuan-ketentuan yang mengatur ganti rugi yaitu pada pasal 1244 dan pasal 1245 KUH Perdata (Badrulzaman, 2001: 25).

Pasal 1244 menyatakan bahwa dalam hal debitur tidak dapat memenuhi kewajiban perikatannya dengan baik maka ia bisa membebaskan diri dari tanggung jawab kerugian, kalau ia berhasil membuktikan bahwa munculnya peristiwa yang menghalangi prestasi sehingga debitur tidak dapat memenuhi kewajiban perikatannya dengan baik atas bagaimana mestinya, tidak dapat diduga sebelumnya dan ia pun tidak punya andil dalam munculnya peristiwa halangan itu.

Mengenai force majeure terdapat dua teori yaitu teori absolut dan teori relatif. Menurut teori absolut, debitur berada dalam keadaan memaksa, apabila pemenuhan prestasi itu tidak mungkin (ada unsur impossibilitas) dilaksanakan oleh siapapun juga atau oleh setiap orang. Dalam ajaran ini pikiran para sarjana tertuju pada bencana alam atau kecelakaan yang hebat. Hal ini terdapat dalam pasal 1444 KUHPerdata yang menyebutkan bahwa "jika barang tertentu yang menjadi bahan persetujuan musnah, tidak lagi dapat diperdagangkan atau hilang, sedemikian hingga sama sekali tidak diketahui apakah barang itu masih ada maka hapuslah perikatannya". 
Jika debitur pada waktu menutup perjanjian sudah menduga atau dapat menduga, bahwa peristiwa yang menghalangi prestasi akan muncul, namun ia tetap menutup perjanjian itu, dan apabila peristiwa tersebut benar-benar terjadi maka hal tersebut patut untuk dipertanggungjawabkan kepada debitur. Jika debitur sudah tahu atau patut menduga, bahwa perang akan segera meletus dan akan ada larangan untuk memperdagangkan barang yang diperjanjikan mengakibatkan debitur tidak dapat memenuhi kewajibannya, dalam pasal 1444 KUHPerdata, debitur tidak mempunyai kesalahan dalam peristiwa tersebut, tetapi kerugian harus dibebankan kepada debitur (Satrio, 1993: 266).

Pasal ini, walaupun mengenai pembayaran ganti kerugian, juga terkait dengan masalah beban pembuktian, yaitu apabila terjadi wanprestasi, debitur dihukum membayar ganti kerugian jika ia tidak dapat membuktikan bahwa terjadinya wanprestasi itu disebabkan oleh keadaan yang tidak terduga atau diluar kemampuan debitur. Debitur mempunyai kewajiban untuk melakukan sesuatu, tetapi ternyata debitur tidak memenuhi kewajibannya, maka timbul kerugian pada debitur. Dalam hal demikian, debitur akan berusaha mengemukakan adanya keadaan memaksa untuk menghindarkan diri dari tuntutan ganti rugi dari kreditur.

Pasal 1243 KUH Perdata mengatur tentang kewajiban ganti kerugian, jika debitur lalai memberikan prestasi. Jika debitur lalai memenuhi kewajiban perikatannya, maka debitur harus dihukum mengganti biaya, rugi, dan bunga apabila debitur tidak dapat membuktikan bahwa tidak dilaksanakannya kewajiban karena hal yang tidak terduga. Agar debitur dapat mengemukakan adanya force majeure maka debitur berkewajiban untuk membuktikan:

a) Debitur tidak mempunyai kesalahan atas timbulnya halangan prestasi.

b) Halangan itu tidak dapat diduga sebelumnya.

c) Debitur tidak menanggung resiko baik menurut undang-undang maupun ketentuan perjanjian atau karena ajaran itikad baik harus menanggung resiko.

Jadi adanya force majeure ini karena perikatan, dimana ada hubungan hukum antara pihak yang satu dengan pihak yang lain termasuk dalam masalah kepailitan perusahaan. Keadaan yang tidak menentu setelah adanya peristiwa pandemi Covid 19 telah memberikan dampak buruk terhadap proses perjanjian pinjam meminjam antara debitur dan kreditur di Indonesia maupun dunia secara keseluruhan. Proses pemberlakuan force majeureoleh Pemerintahan Republik Indonesia dapat memberikan keringanan atas bunga utang yang dihadapi oleh pihak debitur suatu perusahaan untuk saat ini.

\subsubsection{Menjaga Keseimbangan dan Kelangsungan Usaha Perusahaan}

Perseroan Terbatas adalah persekutuan modal yang oleh undang-undang diberi status badan hukum, sebagaimana tercantum dalam UU No 40 Tahun 2007 tentang Perseroan Terbatas (UUPT) Pasal 1 ayat (1) jo Pasal 7 ayat (4) yang berbunyi sebagai berikut: "Perseroan Terbatas yang selanjutnya disebut Perseroan adalah badan hukum yang merupakan persekutuan modal yang didirikan berdasarkan perjanjian, melakukan kegiatan usaha dengan modal dasar yang seluruhnya terbagi dalam saham-saham dan memenuhi persyaratan yang ditetapkan dalam undang-undang ini serta peraturan pelaksanaannya" (Tumbuan, 1990: 87). Selanjutnya Pasal 7 ayat (4) berbunyi: "Perseroan memperoleh status badan hukum pada tanggal diterbitkannya Keputusan Menteri mengenai pengesahan badan hukum".

Persekutuan modal adalah bahwa modal dasar perseroan terbagi dalam sejumlah sahamsaham yang pada dasarnya dapat dipindahtangankan (transferable shares). 
Sehubungan dengan ini perlu ditegaskan bahwa sekalipun semua saham dimiliki oleh 1(satu) orang, konsep persekutuan modal tetap valid karena perseroan tidak menjadi bubar melainkan tetapberlangsung sebagai subyek hukum. Kebenaran ini dipertegas oleh ketentuan Pasal 7 ayat (7) yang mengatur bahwa 100\% saham persero (BUMN berbentuk perseroan terbatas) dapat dimiliki oleh negara dan perseroan yang mengelola bursa efek, lembaga kliring, penjaminan, lembaga penyimpanan dan penyelesaian.

Perbuatan hukum pendirian oleh 2(dua) orang atau lebih pendiri tidak melahirkan perjanjian antara para pendiri, melainkan mengakibatkan adanya perjanjian antara semua pendiri di satu pihak dan perseroan di pihak lain. Berdasarkan perjanjian pendirian dimaksud para pendiri berhak menerima saham dalam perseroan dan sekaligus mereka wajib melakukan penyetoran penuh atas saham yang diambilnya, dengan demikian sesungguhnya antara para pendiri di satu pihak dan perseroan di lain pihak terjadi hubungan keanggotaan dan oleh karena itu perbuatan hukum pendirian oleh para pendiri sekaligus mengakibatkan terjadinya penyertaan oleh semua pendiri dalam perseroan selaku persekutuan modal (Suyatno, 2007: 138).

Perkembangan teknologi dan tuntutan zaman yang semakin hari semakin canggih dan menuju ke arah globalisasi, maka perseroan terbatas sebagai salah satu pilar pembangunanperekonomian nasional perlu diberikan landasan hukum, untuk lebih memacu pembangunan nasional yang disusun sebagai usaha bersama berdasarkan asas kekeluargaan. Pemerintah merasa perlunya memberikan pelayanan yang cepat dalam bidang usaha demi persaingan dalam memperoleh devisa bagi negara. Sebagaimana yang telah berjalan selama ini, pengesahan atau persetujuan perseroan terbatas telah dilakukan melalui media komunikasi internet, agar Departemen Hukum dan Hak Asasi Manusia tersebut tidak perlu didatangi tamu-tamu dari seluruh Indonesia. Selain memproses lebih cepat juga menghemat biaya, hal ini telah pula diserahkan oleh Departeman Hukum dan Hak Asasi Manusia kepada suatu perseroan swasta, yang bernama PT. Sarana Rekatama dinamika yang berkedudukan di Jakarta, yang terkenal dengan sebutan perseroan yang menangani Sisminbakum yaitu singkatan dari sistem administrasi badan hukum.

Dari ketentuan tersebut secara eksplisit sangat jelas disebutkan bahwa perseroan terbatas merupakan badan hukum. Perseroan Terbatas merupakan suatu bentuk (legal form) yang didirikan atas fiksi hukum (legal fiction), bahwa perseroan memiliki kapasitas yuridis yang sama dengan yang dimiliki oleh orang perseorangan (natural person). Apabila dikaitkan dengan unsur-unsur mengenai badan hukum, maka unsur-unsur yang menandai perseroan terbatas sebagai badan hukum adalah bahwa perseroan terbatas mempunyai kekayaan yang terpisah (Pasal 24 ayat (1) UUPT), mempunyai kepentingan sendiri (Pasal 82 UUPT), mempunyai tujuan tertentu (Pasal 12 huruf b UUPT) dan mempunyai organisasi teratur (Pasal 1 butir 2 UUPT) (Kansil \& Kansil, 2005: 96).

Salah satu karakteristik mendasar dari suatu perseroan terbatas sebagai corporation adalah sifat badan hukum dan pertanggungjawaban terbatas dari perseroan terbatas. Dalam kepustakaan hukum Belanda istilah badan hukum dikenal dengan sebutan "rechtsperson", dan dalam kepustakaan tradisi hukum common law seringkali disebut dengan istilah-istilah legal entity, juristic person, atau artificial person (Supramono, 2009: 34).

Pada dasarnya sebelum pernyataan pailit, hak-hak debitur untuk melakukan semua tindakan hukum berkenaan dengan kekayaannya harus dihormati.Tentunya dengan memperhatikan hak-hak kontraktual serta kewajiban debitur menurut peraturan perundang-undangan (Soemitro, 1993: 89). 
Semenjak pengadilan mengucapkan putusan kepailitan dalam sidang yang terbuka untuk umum terhadap debitur berakibat bahwa ia kehilangan hak untuk melakukan pengurusan dan penguasaan atas harta bendanya (persona standy inludicio) dan hak kewajiban si pailit beralih kepada kurator untuk mengurus dan menguasai boedelnya (Mulhadi, 2010: 29). Begitu pula hak-hak pribadi debitur yang tidak dapat menghasilkan kekayaan atau barang-barang mililk pihak ketiga yang kebetulan berada di tangan pailit, tidak dapat dikenakan eksekusi, misalnya: hak pakai dan hak mendiami rumah (Ali, 1982: 67).

Kepailitan badan hukum Perseroan Terbatas, beroperasi atau tidaknya perseroan setelah putusan pailit dibacakan tergantung pada cara pandang kurator terhadap prospek usaha perseroan pada waktu yang akan datang. Hal ini dimungkinkan karena berdasar ketentuan di dalam Pasal 104 UUKPKPU yang berbunyi :(1) Berdasarkan persetujuan panitia kreditor sementara, kurator dapat melanjutkan usaha debitur yang dinyatakan pailit walaupun terhadap pernyataan putusan pailit tersebut diajukan kasasi atau peninjauan kembali. (2) Apabila dalam kepailitan tidak diangkat panitia kreditur, kurator memerlukan izin hakim pengawas untuk melanjutkan usaha sebagaimana dimaksud dalam ayat (1) (Gautama, 1998: 81).

Berdasarkan bunyi pasal tersebut di atas dapat disimpulkan bahwa kepailitan Badan Hukum Perseroan Terbatas di Indonesia tidak secara otomatis membuat perseroan kehilangan haknya untuk mengurus dan menguasai harta kekayaan perseroan tersebut, karena kepailitan perseroan terbatas menurut hukum Indonesia tidak menyebabkan terhentinya operasional perseroan. Akan tetapi dalam hal perseroan yang dilanjutkan ternyata tidak berprospek dengan baik, maka hakim pengawas akanmemutuskan untuk menghentikan beroperasinya perseroan terbatas dalam permohonan seorang kreditur. Setelah perseroan tersebut dihentikan, maka kurator mulai menjual aktiva boedel tanpa memerlukan bantuan/persetujuan debitur pailit (Subekti, 2008: 93), tetapi pasal tersebut di atas tidak berlaku apabila di dalam rapat pencocokan piutang tidak ditawarkan perdamaian atau jika rencana perdamaian yang ditawarkan tidak diterima atau pengesahan perdamaian ditolak sehingga demi hukum harga pailit berada dalam keadaan insolvensi. Kurator atau kreditur yang hadir dalam rapat mengusulkan supaya perseroan debitur pailit dilanjutkan (Pasal 179 ayat (1) dan usul tersebut hanya dapat diterima apabila usul tersebut disetujui oleh para kreditur yang mewakili lebih dari $1 / 2$ (setengah) dari semua piutang yang diakui dan diterima dengan sementara yang tidak dijamin dengan hak gadai, jaminan fiducia, hak tanggungan, hipotik atau hak agunan atas kebendaan lainnya (Pasal 180 ayat (1) (Gunadi, 2001: 98).

Salah satu perubahan yang mendasar dalam perubahan UU No 1 Tahun 1995 menjadi Undang-Undang Nomor 40 Tahun 2007 tentang Perseroan Terbatas (selanjutnya disebut UUPT) adalah mengenai keberadaan tanggung jawab sosial perusahaan dalam pengaturan baru di UU PT, dimana perusahaan didorong untuk dapat bertanggung jawab serta berkontribusi bagi perkembangan masyarakat dalam bidang sosial.

Keberadaan UU PT dalam sistem hukum di Indonesia telah berjalan hampir 10 (sepuluh) tahun memberikan perlindungan hukum mengenai PT mengalami perkembangan kebutuhan masyarakat seiring dengan iklim kompetitif perekonomian secara global untuk menyediakan kemudahan berusaha (ease of doing business) untuk memberikan stimulus terhadap perekonomian secara nasional. Berbagai permasalahan terkait dengan PT sebagai badan hukum adalah terkait dengan dasar pendirian PT, struktur permodalan PT, dan keberadaan dewan komisaris. Selain itu, dari sisi perkembangan masyarakat mengenai 
perlindungan pemegang saham, UUPT Indonesia mendapat respon negatif seiring dengan keberadaan minimnya perlindungan pemegang saham minoritas, hal ini ditunjukan dengan menempatkan Indonesia dalam peringkat 70 (tujuh puluh) dalam indeks yang diukur dalam ease of doing business. Selain itu, keberadaan UUPT yang ada saat ini perlu menyesuaikan perkembangan yang ada sebagaimana ditunjukan dalam penilaian ease of doing business serta perkembangan kebutuhan lainnya di masyarakat, selain itu terdapat beberapa putusan Mahkamah Konstitusi terkait dengan pengujian materil UUPT terhadap UUD NRI Tahun 1945.

Sementara itu, menurut Pasal 74 UUPT, tanggung jawab sosial dan lingkungan diwajibkan terbatas kepada PT yang menjalankan kegiatan usahanya di bidang dan/atau berkaitan dengan sumber daya alam. Saat ini, hampir seluruh PT yang melakukan kegiatan usaha sudah menerapkan dan menjalankan tanggung jawab sosial dan lingkungan secara langsung dan nyata. Kondisi ini menimbulkan kecemburuan bagi PT yang tidak menjalankan kegiatan usahanya di bidang dan/atau berkaitan dengan sumber daya alam karena tidak dapat menerapkan dan mempergunakan penganggaran pelaksanaan tanggung jawab sosial dan lingkungan sebagai bagian dari biaya PT. Ketentuan Pasal 66 ayat (2) huruf (c) yang multitafsir dan tidak jelas ini menyebabkan kewajiban melaksanakan tanggung jawab sosial dan lingkungan berlaku kepada seluruh PT. Rumusan norma sebagaimana dimaksud dalam Pasal tersebut dapat mengakibatkan kendala dalam implementasi penerapannya berupa penolakan masyarakat, dikarenakan perseroan bukan merupakan perseroan yang bergerak dalam bidang lingkungan dan sosial, serta perseroan merupakan perusahaan dalam skala UMKM. Akibatnya ketentuan ini merugikan masyarakat.

Ketentuan ini dikaitkan dengan Pasal 74 yang mengenakan sanksi dalam hal suatu perusahaan tidak melaksanakan ketentuan perundang-undangan untuk melakukan kegiatan tanggung jawab sosial perusahaan. Ketentuan ini dianggap oleh hakim Konstitusi dalam dissenting opinion hakim yang mempunyai alasan berbeda, yang pada pokoknya menyatakan rumusan yang tidak pasti (masih umum) dan tidak menunjuk pada peraturan perundang-undangan yang dimaksud, sehingga pengenaan sanksi tersebut dapat dilaksanakan secara membabi-buta.

Penataan Regulasi harus dilakukan melalui evaluasi atas berbagai peraturan agar sejalan dengan jiwa Pancasila, amanat konstitusi dan kepentingan nasional, dengan dilakukannya penilaian terhadap peraturan perundang-undangan tidak hanya akan memperbaiki materi hukum yang ada (existing), namun juga memperbaiki sistem hukum yang mencakup materi hukum; kelembagaan dan penegakan hukum; pelayanan hukum; serta kesadaran hukum masyarakat.

Dari berbagai latar belakang yang disampaikan di atas pada tahun 2018, Badan Pembinaan Hukum Nasional membentuk kelompok kerja yang akan melaksanakan kegiatan analisis dan evaluasi hukum terkait kepailitan. Analisis dan evaluasi hukum merupakan upaya melakukan penilaian terhadap hukum, dalam hal ini peraturan perundang-undangan sebagai hukum positif, yang dikaitkan dengan struktur hukum dan budaya hukum.

\section{Kesimpulan}

Berdasarkan pembahasan mendalam serta analisis data yang telah dikemukakan diatas, maka dapat disimpulkan bahwa upaya preventif dilakukan bagi debitur dan kreditur dalam perjanjian pinjam meminjam yakni penundaan resiko perjanjian sebelum jatuh tempo. Solusi untuk menjaga kelangsungan usaha dan keseimbangan berusaha maupun pemberian 
force majeure adalah untuk membantu debitur dalam pengelolaan perusahaannya agar terhindar dari resiko pailit.

\section{Daftar Referensi}

Ali, C. (1982). Himpunan Yurisprudensi, Hukum Dagang di Indonesia. Pradnya Paramita.

Badrulzaman, M. D. (2001). Kompilasi Hukum Perikatan. Citra Aditya Bakti.

Gautama, S. (1998). Komentar Atas Peraturan Kepailitan Baru untuk Indonesia. Citra Aditya Bakti.

Gunadi. (2001). Restrukturisasi Perbankan Dan Penyelesaian Utang Dalam Negeri. Salemba Empat.

Kansil, C. S. ., \& Kansil, C. S. T. (2005). Hukum Perseroan Indonesia (Aspek Hukum dalam Ekonomi). Pradnya Paramita.

Mulhadi. (2010). Hukum Perseroan dan Bentuk-Bentuk Badan Usaha di Indonesia. Ghalia Indonesia.

Prawirohamidjojo, S., \& Pohan, M. (1984). Hukum Perikatan. Bina Ilmu.

Saija, R. (2018a). Penyalahgunaan Keadaan Dalam Prosedur Permohonan Pailit Di Pengadilan Niaga. SASI, 24(1), 11-18. https:// doi.org/10.47268/sasi.v24i1.114

Saija, R. (2018b). Perlindungan Kreditur Atas Pailit Yang Diajukan Debitur Dalam Proses Peninjauan Kembali Di Pengadilan Niaga. SASI, 24(2), 114-123. https:// doi.org/10.47268/sasi.v24i2.126

Saija, R. (2021). Perspektif Sanksi Pidana Kurator Menurut Hukum Kepailitan. PAMALI: $\begin{array}{llll}\text { Pattimura MagisterLaw } & \text { Review, }\end{array}$ https:// fhukum.unpatti.ac.id/jurnal/pamali/article/view/480

Satrio, J. (1993). Hukum Perikatan (Perikatan Pada Umumnya). Alumni.

Soemitro, R. (1993). Hukum Perseroan Terbatas, Yayasan Dan Wakaf. Eresco.

Subekti, R. (2008). Hukum Pembuktian. Pradnya Paramita.

Supramono, G. (2009). Hukum Perseroan Terbatas. Djambatan.

Suyatno, T. (2007). Azas-Azas Kepailitan. Percetakan Penebar Swadaya.

Tumbuan, F. B. G. (1990). Pokok-pokok Undang-Undang tentang Kepailitan sebagaimana diubah oleh PERPU No. 1/1998. Ghalia Indonesia.

Wessels, B. (2017). The logic of harmonisation of insolvency law in the EU. Leidenlawblog.N1. http:/ / leidenlawblog.nl/articles/the-logic-of-harmonisation-of-insolvency-law-inthe-eu 